University of Pennsylvania Carey Law School

Penn Carey Law: Legal Scholarship Repository

Faculty Scholarship at Penn Carey Law

6-24-2015

\title{
Human Rights Treaties in and beyond the Senate: The Spirit of Senator Proxmire
}

Jean Galbraith

University of Pennsylvania Carey Law School

Follow this and additional works at: https://scholarship.law.upenn.edu/faculty_scholarship

Part of the American Politics Commons, Constitutional Law Commons, Human Rights Law Commons, International Law Commons, International Relations Commons, Law and Politics Commons, Law and Society Commons, Legal History Commons, and the Public Law and Legal Theory Commons

\section{Repository Citation}

Galbraith, Jean, "Human Rights Treaties in and beyond the Senate: The Spirit of Senator Proxmire" (2015). Faculty Scholarship at Penn Carey Law. 1563.

https://scholarship.law.upenn.edu/faculty_scholarship/1563

This Book Chapter is brought to you for free and open access by Penn Carey Law: Legal Scholarship Repository. It has been accepted for inclusion in Faculty Scholarship at Penn Carey Law by an authorized administrator of Penn Carey Law: Legal Scholarship Repository. For more information, please contact PennlawIR@law.upenn.edu. 


\title{
Human RightS TREATIES IN AND BEYOND THE SENATE: THE SPIRIT OF SENATOR PROXMIRE
}

\author{
Jean Galbraith*
}

The second time I met Roger Clark, he stood on a chair and sang Waltzing Matilda. The occasion was a party celebrating Roger's forty years of teaching at Rutgers-Camden. As the toasts that evening made clear, Roger had become an institution within Rutgers. Everyone knew his hearty New Zealand accent, tracked his running, noted his love of music so pluralist that it included the unofficial Australian anthem, and, above all, acknowledged his devotion to the moral imperatives that underlie international humanitarian and human rights law.

In tribute to Roger, this essay explores issues related to the ratification of human rights treaties in the United States. For supporters, the picture at first is a bleak one. In 1995, Louis Henkin wrote a famous piece in which he suggested that the process of human rights treaty ratification was haunted by "the ghost of Senator Bricker" - the isolationist Senator who in the 1950s had waged a fierce assault on the treaty power, especially with regard to human rights treaties. ${ }^{1}$ Since that time, Senator Bricker's ghost has proved even more real. Professor Henkin's concern was with how the United States ratified human rights treaties - with the packet of reservations, declarations, and understandings (RUDs) attached by the Senate in giving its advice and consent. Today, the question is not how but whether. It is now twenty years since the United States ratified a major human rights treaty.

Yet one common theme that arches across U.S. foreign relations law is the power of the dialectic. "A Hamilton may be matched against a Madison;" "Professor Taft is counterbalanced by Theodore Roosevelt;"3 and the great Supreme Court decisions of Youngstown and Curtiss-Wright stand in tension with one another. ${ }^{4}$ So too in the Senate. The ghost of Senator Bricker may be on the prowl. But opposing him is the spirit of the Senator Proxmire, the late internationalist who for many years led a lonely

* Assistant Professor, University of Pennsylvania Law School. I thank members of the Philadelphia JILSA group for their comments.

${ }^{1}$ Louis Henkin, Editorial Comment, U.S. Ratification of Human Rights Conventions: The Ghost of Senator Bricker, 89 AJIL 341, 341 (1995).

${ }^{2}$ Youngstown Sheet \& Tube Co. v. Sawyer, 343 U.S. 579, 635 n.1 (1952) (Jackson, J., concurring).

${ }^{3}$ Id. (adding that "[i]t even seems that President Taft cancels out Professor Taft").

4 See Harold Hongju Koh, Why the President (Almost) Always Wins in Foreign Affairs: Lessons of the Iran-Contra Affair, 97 YALE L.J. 1255, 1306-09 (1988). 
campaign to keep the Genocide Convention on the Senate's agenda. His spirit is one with whom Roger would enjoy a conversation. ${ }^{5}$ For unlike Senator Bricker, Senator Proxmire believed that the United States should be responsive to international human rights norms. His tenacity ultimately helped lead to the ratification of the Genocide Convention, thirty-nine years after President Truman had signed it.

The spirit of Senator Proxmire embodies two trends in relation to unratified human rights treaties. The first is simply that efforts towards Senate advice and consent for at least some of these treaties persist and persist. While no Senator today can match Senator Proxmire's tenacity, the treaties' supporters keep on trying. The second trend - less direct, but even more interesting - is that unratified human rights treaties are nonetheless influencing the shape of law in the United States. As scholars have documented, these treaties are affecting administrative action, state and local legislation, and judicial interpretation. The most high-profile example is the Supreme Court's citation to unratified human rights treaties in the course of constitutional interpretation. In essence, these uses of unratified human rights treaties are advancing Senator Proxmire's goal of having the United States be responsive to human rights norms, although not doing so through his preferred means of treaty ratification.

There is an intriguing parallel between how isolationists and internationalists have used what might be considered second-best legal tools in order to pursue their goals. Just as Senator Bricker did not achieved a constitutional amendment limiting the treaty power but his spiritual descendants used RUDs to similar effect, so advocates of human rights treaties are failing to achieve their ratification yet making them count in other ways. In both cases, opponents have cried foul. Professor Henkin viewed the use of certain RUDs as bordering on unconstitutional, and those wary of international influences view uses of unratified human rights treaties as inappropriate dodges around the constitutional process for treaty advice and consent. But in both cases, the practice has embraced halfmeasures.

\section{Human Rights TREAties IN THE SENATE FROM 1995 TO 2014}

In the early 1990s, the United States seemed on the cusp of abandoning its longstanding aloofness to human rights treaties. In 1992, the United States ratified the International Covenant on Civil and Political Rights (ICCPR) and in 1994 it ratified the Convention on the Elimination of All Forms of Racial Discrimination (CERD) and the Convention against

\footnotetext{
${ }^{5}$ For an example of Roger's fondness for conversation with friendly ghosts, see Roger S. Clark, The International Criminal Law System, 8 N.Z. J. PUB. INT’L L. 27, 27 (2010).
} 
Torture (CAT). Writing in 1995, Professor Henkin observed that ratification of the Convention on the Elimination of All Forms of Discrimination against Women (CEDAW) was "expected in 1995" and added that the United States "might adhere to several [other human rights treaties] before long." 6

Professor Henkin's predictions were overly optimistic. CEDAW did not receive ratification in 1995 and nor has any major human rights treaty since. CEDAW remains formally before the Senate, as do the American Convention on Human Rights and the International Covenant on Economic, Social and Cultural Rights (ICESCR). ${ }^{7}$ In addition, in 2012 the Obama Administration transmitted the Convention on the Rights of Persons with Disabilities (CRPD) to the Senate. But since 1994, the only Senate resolutions of advice and consent on human rights treaties have involved treaties dealing with discrete issues of children's rights. Thus, in 2002, the Senate advised and consented to the first two optional protocols to the Convention on the Rights of the Child, one of which deals with children in armed conflict and the other of which deals with the sexual exploitation of children. ${ }^{8}$ (As to the actual Convention on the Rights of the Child, the United States signed it in 1995, but to date the President has not transmitted it to the Senate for advice and consent.)

Three things are particularly notable about the failure of human rights treaties to make it through the Senate. First, this failure comes despite the willingness of supporters of these treaties to accept RUDs that limit the treaties' practical effects. Second, this failure is part of a broader trend in treaty non-ratification, although the trend is particularly strong with regard to human rights treaties. And third, despite everything, some human rights treaties remain meaningfully, not simply formally, on the Senate's

\footnotetext{
${ }^{6}$ Henkin, supra note 1 , at 341 . The process by which the United States joins international agreements varies depending on what constitutional process the United States considers appropriate and on whether signature/ratification/accession is called for under international law. For purposes of this essay, I focus on the approach employed to date in the context of human rights treaties. This is that the President signs the treaty; the President then transmits the treaty to the Senate for advice and consent; the Senate advises and consents, implementing legislation is passed if deemed necessary (although this could theoretically happen after ratification as well), and then the President ratifies the treaty on behalf of the United States. There is no certainty that a treaty will progress from any one step to the next step.

7 This information, as well as information about other pending treaties before the Senate, can be found on the THOMAS Treaties database, at http://thomas.loc.gov/home/treaties/treaties.html.

8148 Cong. Rec. 10683-85 (June 18, 2002). Since 1995, the Senate has also advised and consented to a number of treaties that, though classified as belonging to areas like arms control, labor, organized crime, and private international law, nonetheless have human rights dimensions.
} 
agenda.

During the advice and consent process for human rights treaties in the early 1990s, there was debate over how willing supporters of human rights treaties should be to accept RUDs in order to get the treaties through the Senate. Scholars raised concerns about the validity of some of these RUDs under international and U.S. constitutional law. ${ }^{9}$ Ultimately, however, the treaties approved in the early 1990s came with significant RUDs. As Curtis Bradley and Jack Goldsmith have argued, these RUDs "helped break the logjam in domestic politics that had prevented U.S. ratification of any of the major human rights treaties."10

Today, the inclusion of RUDs for the ratification of any human rights treaties seems a given, although the executive branch may push back on the addition of specific RUDs. Yet despite this, even the human rights treaties with the most support - CEDAW and the CRPD - have not received advice and consent. Following hearing on CRPD in late 2013, for example, the ranking Republican member on the Senate Foreign Relations Committee announced that he could not support it, saying that he was "uncertain that even the strongest RUDs would stand the test of time."11

The failure of human rights treaties to make it through the Senate is part of a broader trend. Since the 1994 election cycle, the slightest whiff of controversy has usually been enough to doom a treaty. In the decade from 2000 through 2010, for example, only one treaty received the Senate's advice and consent where there were any recorded "no" votes. ${ }^{12}$ Part of this is due to the stiffness of the two-thirds requirement, and part of it is due to the procedural difficulties of getting to a floor vote. ${ }^{13}$ Where disputed treaties have made it through the Senate, it has been because of deep engagement by the executive branch from the President down, as with the New START Treaty under the Obama Administration and earlier with the Chemical Weapons Convention under President Clinton. This engagement has not seemed as powerful in the human rights context.

The ghost of Senator Bricker would doubtless applaud these developments. The particular legal mechanism most called for by Senator

\footnotetext{
${ }^{9}$ See Curtis A Bradley \& Jack L. Goldsmith, Treaties, Human Rights, and Conditional Consent, 149 U. PA. L. REV. 399, 401 n. 4 (2000) (citing sources).

${ }^{10} \mathrm{Id}$. at 459.

11 http://www.corker.senate.gov/public/index.cfm/2013/12/corker-advocating-for-u-sdisability-rights-abroad-should-not-come-at-the-expense-of-the-constitution

${ }^{12}$ This was the New START Treaty. Jean Galbraith, Prospective Advice and Consent, 37 YALE J. INT’L L. 247, 287 (2012).

${ }^{13} \mathrm{Id}$. at 296. For a discussion and explanation of how the procedural hurdles to treaty ratification are higher in the United States than in most other countries in the world, see Oona Hathaway, Treaties' End: The Past, Present, and Future of International Lawmaking in the United States, 117 YALE L.J. 1238, 1271-74 (2008).
} 
Bricker in the early 1950s, when he served in the Senate as a Republican from Ohio, was a constitutional amendment that would have limited the extent to which treaties could deal with issues outside of Congress's powers under Article I of the Constitution and the extent to which treaties could be self-executing. ${ }^{14}$ Senator Bricker was unsuccessful in getting such an amendment through the Senate, let alone any further. But as Professor Henkin observed in his famous essay, Senator Bricker would likely have approved of the inclusion of RUDs regarding federalism and non-selfexecution, as these effectively reach his desired result with regard to the particular treaties to which they are attached. ${ }^{15}$

Even more to the point, Senator Bricker would doubtless have rejoiced at the fact that human rights treaties are now not getting ratified at all. Senator Bricker's push for a constitutional amendment came largely out of an isolationist desire that the United States not ratify human rights treaties - a desire expressed at a time when those who favored racial integration saw human rights treaties as a means of ending segregation. Bricker indicated that "the rights of the individual constitute a subject essentially within the domestic jurisdiction of his country." 16 While he expressed a wish for the United States to "play a leading part in advancing the cause of human rights all over the world," he did not want any international influence on rights within the United States. ${ }^{17}$ Ultimately, Bricker won a commitment from the Eisenhower Administration that it would promote human rights through "persuasion, education, and example rather than formal undertakings" and would not seek to join human rights treaties. ${ }^{18}$ The failure of the United States since 1995 to ratify any human rights treaties is in keeping with Bricker's philosophy that while the United States may promote human rights abroad, it should treat them as strictly domestic issues at home.

But there is a third piece to the experience of human rights treaties in the Senate since 1995. This is that there continues to be active pursuit of advice and consent of at least some of these treaties. While ICESCR and the American Convention have not received serious consideration since the Carter Administration, both CEDAW and CRPD have substantial support in

\footnotetext{
${ }^{14}$ For a discussion of the various variants of the Bricker Amendment, and of the relative perspectives of Senator Bricker and his allies in the American Bar Association, see Rowland Brucken, A Most Uncertain Crusade: The United States, the United NATIONS, AND HuMAN RigHTS 1941-1953, at 214-53 (2014).

${ }^{15}$ Henkin, supra note 1 , at 349.

1697 Cong Rec. 11512 (Sept. 18, 1951).

1797 Cong Rec. 11514 (Sept. 18, 1951).

18 Treaties and Executive Agreements: Hearings Before a Subcommittee on the Judiciary, 83rd Congr. 825 (1953) (statement of Secretary of State Dulles).
} 
the Senate. $^{19}$ In 2002, the Senate Foreign Relations Committee voted CEDAW forward to the full Senate, although it never received a floor vote, and in 2010 it was the subject of a hearing by the Senate Judiciary Committee's Subcommittee on Human Rights and the Law. In 2012, the Senate Foreign Relations Committee voted CRPD forward to a full Senate and it did receive a floor vote, although with a 61-38 vote it fell short of receiving the necessary two-thirds for advice and consent. The Committee held hearings again on CRPD in November 2013, although opposition from the ranking Republican on the Committee signals that it will not go forward further in this session. It is unclear whether these treaties will ever get through the Senate, and CEDAW has now been before the Senate for thirtyfour years - since its transmission by the President in 1980. But, its supporters continue to try.

\section{SENATOR PRoxmire AND THE GENOCIDE CONVENTION}

The case of the unratified human rights treaties pending in the Senate might seem hopeless. Yet the story of the Genocide Convention offers a powerful example otherwise. ${ }^{20}$ The Genocide Convention was transmitted to the Senate in 1949, but it did not receive advice and consent until 1986 - thirty-seven years later - and another two years would pass before the United States ratified it. Its ultimate approval owed much to Senator Proxmire, the Democrat from Wisconsin.

Senator Proxmire's views on human rights treaties were the antithesis of Senator Bricker's. To Senator Proxmire, "[t]he cause of human rights transcends national boundaries." 21 He believed that as "the foremost democratic nation in the world, the United States has a major role to play in promoting universal adherence to international law, based on concrete guarantees of freedom and justice."22 In his view, the U.S. failure to ratify human rights treaties was "deplorable" and an "embarrassment" ${ }^{23}$

Beginning in 1967, Senator Proxmire took up the cause of the Genocide Convention in the Senate. His commitment was unswerving. As

19 The details given below can mostly be found on the THOMAS Treaties database cited supra note 7; see also LUISA BLANCHFIELD, CONG. RESEARCH SERV.: THE U.N. CONVENTION ON THE ELIMINATION OF ALL FORMS OF DisCRIMINATION AGAINST WOMEN (CEDAW): Issues In ThE U.S. RATIFICATION DEBATE 7-8 (2013).

${ }^{20}$ For a discussion of the provisions of the Genocide Convention, see Roger S. Clark, State Obligations under the Genocide Convention in Light of the ICJ's Decision in the Case Concerning the Application of the Convention on the Prevention and Punishment of the Crime of Genocide, 61 RuTGERs L. REV. 75 (2008).

${ }^{21} 122$ Cong. Rec. 409 (1976).

22122 Cong. Rec. 8279 (1976).

23125 Cong. Rec. 3048 (1979). 
the Senate Majority leader - a Republican - admiringly observed in 1985:

Senator Proxmire has set a record for persistence that may never be broken. He has spoken on this subject every day the Senate has been in regular session since January 11, 1967. He has made more than 2,900 speeches on the subject, all told, and he seems no less committed to the issue today than when he gave his first speech 17 years ago. ... The Senator has not been deterred by the fact that this treaty and his efforts to ratify it have not received elaborate media attention. He has not been deterred by the fact that a legislative 'hold' was placed on this measure by the late Senator John Bricker and seems never to have been cleared. He has not been deterred by anything at all ...24

In 1970, the Senate held its first hearings on the Genocide Convention since the era of John Bricker. The Foreign Relations Committee or subcommittees thereafter held hearings in 1971, 1973, 1976, 1981, and 1984, but never received a floor vote despite being voted favorably forward out of committee in many of these years. ${ }^{25}$ It was not until the Congressional session held in 1985-1986 when, with the support of President Reagan, the Genocide Convention successfully made it through committee and to a floor vote, where it was overwhelmingly approved with 83 votes in favor and 11 votes against.

This approval came with a set of RUDs, although a less powerful packet than would accompany those human rights treaties which the Senate approved in the early 1990s. Senator Proxmire resisted at least some of these RUDs, but ultimately recognized that this was "the only way that we could possibly do it." 26 He had been forced to compromise, but with the compromise came the treaty's passage, at long last, and an example of persistence that offers hope for those seeking the ratification of other human rights treaties today.

24131 Cong. Rec. 20013-14 (1985) (statement of Sen. Baker) (emphasis added); see also SAmantha Power, “A PROBlem FRom Hell”: AMERICAN AND THE AGE OF GENOCIDE 166 (2002) (tallying 3211 speeches from 1967 to 1986).

${ }^{25}$ For a full account of the Genocide Convention's time in the Senate, see LAWRENCE J. LeBlanc, The United States And the Genocide Convention (1991).

${ }^{26} 132$ Cong. Rec. 2153 (1986); see also 131 Cong. Rec. 20875 (1985) (expressing disagreement with the two reservations attached by the Senate Foreign Relation Committee, one of which reserved out of the International Court of Justice (IJC) jurisdiction and the other or which contained the unnecessary statement that nothing in the Convention authorized action by the United States that was prohibited by the Constitution); POWER, supra note 24, at 167 (discussing the mixed feelings of Proxmire's staff on the Convention's passage with the RUDs). The resolution of advice and consent also included an understanding that the Convention not be ratified until implementing legislation was passed. This implementing legislation, which criminalized genocide under U.S. law, was known as the Proxmire Act; and after its passage in 1988 the United States at last ratified the Genocide Convention. Id. at 167-68. 


\section{PROXMIRE, BRICKER, AND THE GLASS HALF-FULL}

Senator Proxmire's example inspires the continuing efforts to get human rights treaties through the Senate. In addition, at a higher level of generality, the internationalist vision he espoused has to some degree occurred through other means. For although it is very hard to get human rights treaties through the Senate, even unratified treaties can have direct effects on U.S. law. In other words, the integration of international human rights law into the United States that Senator Proxmire called for has come to pass in certain respects despite the inaction in the Senate. These developments have in turn led to objections that parallel the objections made to the ghost of Senator Bricker in interesting respects.

Human rights treaties influence U.S. law in myriad ways even when the United States has not ratified them. These influences appear in executive branch action, in legal decision-making by state and local governmental actors, and in federal judicial decisions. These influences are sporadic rather than comprehensive, and when they occur it is hard to assess how significant they are. Yet there is no denying the existence of these influences. Indeed, as Johanna Kalb has observed, in some ways the influence of unratified human rights treaties in U.S. law may be even stronger than the influence of those human rights treaties that have been ratified with RUDs. ${ }^{27}$

Unratified human rights treaties undoubtedly affect the engagement of the executive branch with other countries (such as at the Universal Periodic Review), but they can also have internal effects as well. For example, a 1995 Department of Justice guideline for asylum officers on dealing with gender-related asylum claims explained that the "evaluation of gender-based claims must be viewed within the framework provided by existing international human rights instruments" and identified CEDAW as the "most comprehensive" such instrument for women. ${ }^{28}$ Internal effects of these unratified human rights treaties can also occur where state and local legislators, executive officials, or judges draw upon them. Perhaps the most

\footnotetext{
${ }^{27}$ Joanna Kalb, The Persistence of Dualism in Human Rights Treaty Implementation, 30 YALE L. \& POL'y REV. 71, 73 (2011) (finding that although state and local “engagement with [human rights] treaties is generally limited, it has occurred more frequently with respect to unratified human rights treaties than it has with those that have been ratified").

${ }^{28}$ Memorandum from Phyllis Coven, Office of International Affairs to All INS Asylum Officers re Considerations for Asylum Officers Adjudicating Asylum Claims for Women 2 (May 16, 1995), available at http://www.refworld.org/docid/3ae6b31e7.html; see also Fisher v. INS, 79 F.3d 955, 967 (1996) (Noonan, J., dissenting) (discussing this guideline). One possibility from a legal perspective is the obligations stemming under international law from treaty signature (as opposed to ratification), but it is beyond the scope of this Essay to analyze the reach of these obligations.
} 
famous example is the San Francisco ordinance implementing CEDAW within the city, but this is only one of many instances. ${ }^{29}$

While the most substantively significant uses of unratified human rights treaties may occur in the executive branch and in state and local governments, the uses that have attracted the most scholarly attention - and also popular attention - have occurred in the federal courts. One such use, which I will not otherwise discuss, is the role that unratified human rights treaties play in informing customary international law norms which in turn may be used by the courts in contexts like cases brought under the Alien Tort Statute. Another use occurs in Supreme Court constitutional decisions where the Court references international norms embodied in unratified human rights treaties. There have been a handful of such uses in the last fifteen years, but I will focus on the 2005 decision in Roper v. Simmons. ${ }^{30}$ Roper is perhaps the most prominent such use and it deals with an issue that Roger cares deeply about: the death penalty.

Specifically, Roper considered whether the Constitution bars the death penalty for persons who committed their crimes as juveniles. This is an issue as to which the United States has avoided treaty commitments: it entered a reservation with respect to this prohibition in Article 6(5) of the ICCPR and, as mentioned earlier, it has not ratified the CRC, which contains a similar prohibition. ${ }^{31}$ Yet in holding that the Constitution does prohibit the death penalty for crimes committed by underage perpetrators, the Supreme Court cited these treaty provisions, as well as some other international and comparative law sources. ${ }^{32}$ The Court did not claim to put much weight on these provisions, simply saying that they "provide[d]

${ }^{29}$ For examples of state and local legislative and executive action, see Columbia Law School, Human Rights Project, Bringing Human Rights Home at 10-23 (2012), available at http://web.law.columbia.edu/sites/default/files/microsites/human-rightsinstitute/files/Bringing\%20Human\%20Rights\%20Home.pdf. For an example of the extensive scholarly literature on the subnational incorporation of international human rights treaties, see Catherine Powell, Dialogic Federalism: Constitutional Possibilities for Incorporation of Human Rights Law in the United States, 150 U. PA. L. Rev. 245 (2001). For an example of a state supreme court drawing on an unratified human rights treaty in interpreting its own constitution, see Diatchenko v. District Attorney for Suffolk Dist., 1 N.E. 3d 270, 285 n.6 (Mass. 2013).

30543 U.S. 551 (2005). Other cases in which the Supreme Court has referenced international law in its constitutional decisions include Graham v. Florida, 560 U.S. 48, 8082 (2010) (dealing with life sentences without the possibility of parole for crimes that were not murders that were committed by juveniles); Lawrence v. Texas, 539 U.S. 558, 573-77 (2003) (dealing with the criminalization of consensual same-sex intimate conduct within a home); Atkins v. Virginia, 536 U.S. 304, 316-17 (2002) (dealing with the death penalty for the mentally disabled).

${ }^{31} 543$ U.S. at 576.

${ }^{32} \mathrm{Id}$. 
respected and significant confirmation for our own conclusions," but it nonetheless made a very deliberate choice to discuss them.

The pushback against this use of unratified human rights treaties was immediate and emphatic. In dissent, Justice Scalia observed that "[u]nless the Court has added to its arsenal the power to join and ratify treaties on behalf of the United States, I cannot see how this evidence favors, rather than refutes" the Court's conclusion that the death penalty is unconstitutional as applied to juveniles. ${ }^{33}$ His dissent was only the beginning of attacks on the Supreme Court's use of international and comparative law in constitutional interpretation. These attacks, which came from both scholars and politicians, argued that these uses were constitutionally impermissible, either because they involved non-originalist materials or because they reflected values that came from outside the U.S. democracy. ${ }^{34}$

I wish to suggest that there are interesting parallels between these objections and the objections raised by Professor Henkin and others to the Senate's attachment of RUDs to human rights treaties. The overarching parallel is that both types of objections employ formalist reasoning, but three more specific similarities can be observed as well.

First, for the objectors in both cases, the right outcome is a bright line. As Justice Scalia has explained in a speech, "[i]t is my view that modern foreign legal materials can never be relevant to an interpretation of - to the meaning of - the U.S. Constitution." ${ }^{35}$ Comparably, for Professor Henkin, human rights treaties should be embraced with few if any RUDs and be self-executing within the United States. ${ }^{36}$

Second, the objectors in both cases suggest that the actual outcome smacks of some kind of cheating. To Justice Scalia, if human rights treaties lack the votes to get through the Senate despite all the efforts of their Proxmire-like supporters, then it is unfair for these treaties to matter anyway. To Professor Henkin, it was problematic that while "Senator Bricker lost his battle" for a constitutional amendment, "his ghost is now enjoying victory in war" through the RUDs that "achieve[] virtually what the Bricker Amendment sought, and more.”37

Third, and perhaps most significantly, these objections are linked to constitutional arguments that have a strongly originalist flavor. Justice

${ }^{33} \mathrm{Id}$. at 578.

${ }^{34}$ See Jean Galbraith, International Law and the Domestic Separation of Powers, 99 VA. L REV. 987, 989 n.6 \& 996 nn. 18-19 (2013) (identifying sources).

${ }_{35}$ Antonin Scalia, Foreign Legal Authority in the Federal Courts, 98 AM. Soc. INT’L L. Proc. 305, 307 (2004). For convenience, I focus here on Justice Scalia and Professor Henkin, although this analysis also applies to others with similar views.

${ }^{36}$ See Henkin, supra note 1, at 349-50.

${ }^{37}$ Henkin, supra note 1 , at 349. 
Scalia's objection to the use of modern international and comparative materials is basically that these materials do not reflect the original understanding of the Constitution. He has observed that once judicial interpreters adopt a "“living Constitution' paradigm” ... then "there is no reason foreign materials should not be used along with all others." 38 For his part, Professor Henkin expressed particular disapproval of declarations of non-self-execution on the ground that the text of the Supremacy Clause makes treaties the "law of the land" " and "there is no evidence of any intent, by the Framers ... to allow the President or the Senate, by their ipse dixit, to prevent a treaty that by its character could be law of the land from becoming law of the land."39

To say that these arguments have parallels is by no means to equate their rightness or wrongness as a matter of legal doctrine or normative desirability. As a matter of positive experience, however, constitutional practice in foreign relation law has rarely favored bright lines or purely embodied originalist positions. Instead, history offers an account of complexity that lends itself to flexibility. In response to Professor Henkin, Professors Bradley and Goldsmith observed that the Senate has a long history with regard to RUDs and other devices for adding conditions to treaties. ${ }^{40}$ Similarly, in response to the arguments of Justice Scalia and others, Sarah Cleveland and others have shown that the Supreme Court has long turned to international law in the course of constitutional interpretation. ${ }^{41}$ In the past, in the present, and - we can expect - in the future, these patterns will continue.

The spirit of Senator Proxmire thus cannot claim complete victory. The cup does not overfloweth - but it is at least half full. If human rights treaties in the United States do not serve as powerful a role in the United States as they do in Europe, yet they do play far more of a role than Senator Bricker and his spiritual descendants would wish them too. Both ghosts can be heard as we pass by the billabong. Which one speaks louder depends on the choices of the living. So, drawing from Roger, "“[s]tave off becoming immortal as long as you can - it can lead to too many regrets if you are no longer out there fighting the good fight!",42

${ }^{38}$ Scalia, supra note 35 , at 308.

${ }^{39}$ Henkin, supra note 1, at 346-47. Professor Henkin shows some equivocation on this point, in part because of his prior defense of a "special case" of non-self-execution in the 1950s. See id. at 347 \& n.26.

${ }^{40}$ Bradley \& Goldsmith, supra note 9, at 403-09.

${ }^{41}$ Sarah H. Cleveland, Our International Constitution, 31 YALE J. INT’L L. 1 (2006).

${ }^{42}$ Clark, supra note 5, at 27 (quoting from his conversation with the statute of the late Peter Fraser). 